\title{
The Determinants of Trade Credit: Evidence from Indian Manufacturing Firms
}

\author{
Rajendra R. Vaidya \\ Indira Gandhi Institute of Development Research, Mumbai, India \\ E-mail:vaidya@igidr.ac.in,vaidya_1962@yahoo.com \\ Received July 5, 2011; revised August 10, 2011; accepted August 20, 2011
}

\begin{abstract}
Trade credit (accounts receivable and accounts payable) is both an important source and use of funds for manufacturing firms in India. This paper empirically investigates the determinants of trade credit in the Indian context. The empirical evidence presented suggests that strong evidence exists in support of an inventory management motive for the existence of trade credit. Highly profitable firms both give and receive less trade credit. Firms with greater access to bank credit offer less trade credit to their customers. On the other hand, firms with higher bank loans receive more trade credit. Holdings of liquid assets have a positive influence on both accounts receivable and accounts payable.
\end{abstract}

Keywords: Trade Credit, Inventories

\section{Introduction}

Trade credit (measured by accounts receivable and accounts payable in the balance sheet of a firm) is an arrangement that allows firms to buy goods or services without making an immediate payment. It thus allows the separation of the exchange of goods and money over time. It is well recognized that trade credit is likely to be a very expensive source of credit ${ }^{1}$. Trade credit (with respect to both the amounts and terms) varies substantially across firms and industries and a substantial body empirical research exists that attempts to explain this variation.

Many theories have been put forward to explain the existence of trade credit. Trade credit may be used as a source of funds if raising capital through other sources is more expensive. Price discrimination being illegal in many countries, firms may choose to discriminate between buyers using trade credit. Some firms may choose to make early payments to take advantage of discounts while others may have an incentive to pay towards the end of the credit period. Suppliers may have some funding advantage over banks in evaluating and controlling credit risk. If suppliers are likely to interact much more closely and more often with buyers compared to banks then this is likely to give them a better idea of the busi-

\footnotetext{
${ }^{1}$ Pertersen and Rajan [1] and Cunningham [2] report and effective
} annualized interest rate upwards of $40 \%$. ness prospects that the buyer faces. If the good supplied cannot be resold by the buyer then the supplier could hold of the threat of stopping supplies if payments are not made in time. Suppliers may also have an advantage over banks with respect to repossessing and reselling the goods supplied in case of default. Trade credit may arise as a financial response to variable demand. Trade credit can be seen an outcome of interaction between product and financial markets which arises because it provides the seller with an advantage in inventory management. Sellers can reduce their finished good inventories by offering trade credit. When business conditions are bad (i.e. inventories pile up) firms may choose to postpone payments for raw materials purchased. Trade credit may also enable firms to lower transactions costs.

At an empirical level most studies relate accounts payable and accounts receivable to various accounting ratios and firm and industry characteristics. A few studies have attempted to examine variations in the terms and conditions of trade credit. Widely cited empirical studies like Petersen and Rajan [1] and Ng, Smith and Smith [3] have uncovered many empirical regularities but overwhelming support or rejection for any particular theory has as yet not been possible.

Trade credit has been generally recognized as an important component of corporate finance in many countries $^{2}$. Recent data, from the Reserve Bank of India ${ }^{3}$, shows that accounts receivable accounted for $10.86 \%$ 
and accounts payable accounted for $11.59 \%$ of total assets/liabilities respectively in 2008 for a sample of large public limited companies. The comparable figure of short term bank credit was $10.75 \%$. Evidently, in India, trade credit is at least as important as bank credit. In most advanced countries accounts receivables can be easily collateralized. This makes it possible for firms to obtain additional bank credit against their accounts receivables. Consequently, a firm providing trade credit does not necessarily have to reduce its investment in other avenues. In India banks have always been somewhat reluctant to lend against accounts receivable ${ }^{4}$. Bills discounted accounted for less than one percent of total credit advanced by Scheduled Commercial Banks in India as of March $2009^{5}$. This institutional feature is likely to have a significant impact on the determinants of trade credit in India.

Unfortunately no systematic empirical evidence on the determinants of trade credit in India is available. This paper makes a small beginning in that direction. We do not deal with the issue of terms and conditions of trade credit due to lack of information in this regard in the Indian context. We estimate a model similar to Bougheas, Mateut and Mizen [11] to study the determinants of trade credit in India. It is found that trade credit arises essentially as a financial response to variable demand and variables suggested by other theories compliment this basic explanation. In the next section a brief summary of the existing theories of trade credit and empirical work that seeks to explain inter firm differences is provided. Section 3 outlines the empirical model used, data sources and results. Section 4 concludes.

\section{Theories of Trade Credit}

Many reasons have been put forward to explain why firms may offer or accept trade credit. We provide below a short outline of the main arguments.

Metzler [12] was possibly the first to point out that large firms use trade credit instead of direct price reductions to push sales in periods when monetary conditions

\footnotetext{
${ }^{2}$ Rajan and Zingales [4] report that trade credit accounted for $17.8 \%$ of total assets of American firms in the early part of 1990s. Kohler, Britton and Yates [5] report that in the U.K. 70\% of total short term debt extended to firms and 55\% of total short term credit received by firms was in the form of trade credit. Uesugi and Yamashiro [6] report that trade credit (accounts payable) accounted for 15.5 of total assets in Japan. Deloof and Jegers [7] report that in 1995 accounts receivable formed $16 \%$ of total assets and accounts payable formed $12 \%$ of total liabilities of Belgian non financial firms.

${ }^{3}$ These figures are based on a sample of 1558 large public limited companies published in the Reserve Bank of India Bulletin March 2010 [8]. ${ }^{4}$ See Report of the Working Group on Discounting of Bills by Banks [9], for a detailed discussion.

${ }^{5}$ Basic Statistical Returns of Scheduled Commercial Banks in India, Reserve Bank of India, Mumbai, Table no. 1.14. [10].
}

were tight. Further, he argued that firms would accumulate liquid balances in periods of loose monetary policy and utilize these to extend trade credit in periods when monetary conditions were tight. These macroeconomic implications of trade credit have been recently further investigated by Guariglia and Mateut [13] and Mateut, Bougheas and Mizen [14] who conclude that in the UK trade credit increases in periods when monetary policy is tight and bank lending falls.

Brennan, Maksimovic and Zechner [15] argue that if the product market is non-competitive and there exists an adverse selection problem in credit markets then this makes price discrimination through trade credit potentially profitable. Imperfections in the product market allow sellers to use trade credit to discriminate between buyers who have different reservation prices. When the credit characteristics of firms to whom the supplier (who has market power in the product market) is attempting to sell cannot be observed by him, trade credit makes it possible to provide incentives for firms to self select. "Good firms" might find it profitable to buy on a cash basis or repay as soon as possible (given the high cost of trade credit) while risky firms may find it advantageous of buy on credit because other source of funds may be even more costly for this firm. An empirical implication that arises from the price discrimination arguments is that more profitable firms are more likely to grant more trade credit.

The possibility that sellers who have easier access to the capital market may have an incentive to offer trade credit to their buyers (who may not have access to capital markets on the same terms) was first pointed out by Schwartz [16]. The supplier's greater ability to raise funds is used to pass credit to their customers. If banks are the main source of credit then this suggests that firms offering trade credit would borrow from banks and pass this on as accounts receivable (on their books of accounts) to the buyers. Biais and Gollier [17] have pointed out that in a situation where banks are forced to ration credit (which arises due to adverse selection), trade credit can transmit a seller's private information to banks. If the seller is willing to offer trade credit to a firm this tells the banks that the supplier has private information regarding this firm which makes it credit worthy. This would lead to a reduction of credit rationing. In addition, Jain [18] has argued that suppliers may have a monitoring advantage over banks because in the course of their transactions with the firm they have access to information which banks may not.

Burkart and Ellingson [19] argue that this monitoring advantage arises because of an intrinsic difference between inputs and cash. Inputs cannot be as easily (if at all) be diverted as cash. It is the fear of diversion of funds 
that induces banks to restrict lending. Trade credit becomes a means to overcome a moral hazard problem created by this possibility. The fact that the firm has received trade credit signals that the firm has bought inputs that cannot be diverted and this opens up the possibility that returns from investing would be higher than the returns from diverting funds. Thus if a bank observes that a firm is receiving trade credit it may be willing to lend. Consequently, firms whose investments are constrained by their access to external funds, trade credit and bank credit may be compliments. Firms whose investments are not constrained by availability of external funds the fact that a firm has/or has not received trade credit is of no consequence, and, bank credit and trade credit may be substitutes. Even though firms can use accounts receivable as collateral there would always be a ceiling on the amount a bank would lend through this channel. Burkart and Ellingsen [19] argue that “... firms that are credit constrained but highly profitable abstain from investing in receivables, leaving the extension of trade credit to firms either have better access to funds or are constrained and relatively unprofitable (pp. 570).” This conclusion would be reinforced in a context where banks do not accept account receivable as collateral.

Cunat [20] argues that firms offering trade credit may have an advantage over banks in enforcing debt repayment in a situation where it is difficult for the buyer to find alternative suppliers and it is costly for the seller to find alternative customers. This condition would be met if the product in question has some technological specificity. This advantage arises because suppliers can threaten buyers with stoppage of supplies of the intermediate good which in turn would hit production. Suppliers would be in a position to help buyers overcome temporary liquidity shocks by offering trade credit. Lee and Stowe [21] point out that trade credit when offered represents an implicit product guarantee of the products quality. The buyer is able to verify the quality of the product before making a payment. In the presence of information asymmetry large discounts (inducements to make quick payments) would covey information on quality. Firms, whose products are of a lower quality, other things being equal, would offer large discounts.

From a transactions cost perspective, a supplier can reduce inventory carrying costs if the buyer's costs of holding inventories are lower. Emery [22] argues that trade credit arises as a financial response to variable demand. Consider a situation where a firm experiences a sudden dip in demand. The firm has two choices. Either to accumulate costly inventories (which may or may not be sold in later periods) or offer trade credit to its customers who may be finance constrained. There clearly exists a trade-off between holding inventories and offer- ing trade credit. For trade credit to be a mutually beneficial arrangement the firm offering trade credit must have an advantage in bearing the financial cost (of the dip in demand) but must be at a disadvantage in terms of the operational cost for holding higher finished goods inventories. The firm that accepts trade credit gains from the fact that implicitly he receives a lower price (if the payment is made within the stipulated period) and the seller gains because of lower inventory costs. Bougheas, Mateut and Mizen [11] incorporate this basic idea in a formal two period model which incorporates the tradeoff between inventories and trade credit under conditions of stochastic demand. Using this model they derive empirically testable propositions with respect to accounts payable and accounts receivable and their relationship with changes in costs of inventories, profitability, risk profile, liquidity position of firms and bank loans. They show that:

a) firms with higher stock of inventories would have lower accounts receivables and accounts payables.

b) profitability will be positively related to both accounts payable and accounts receivable.

c) The relationship of accounts receivable and accounts payable with riskiness of a firm and its liquidity position is indeterminate.

d) Accounts receivables would be positively related to bank loans i.e. they are compliments. Accounts payable can either be positively or negatively related to bank loans.

The empirical literature has unearthed quite a few robust relationships between extent of trade credit offered and received and various firm characteristics. A large variety of variables measuring various firm characteristics have been used to explain inter firm variations in both accounts receivable and accounts payable.

A large number of papers [Petersen and Rajan [1], Deloof and Jegers [7], Miwa and Ramseyer [23] and Bougheas et al. [11], among others] report a positive relationship between accounts payable and accounts receivables and size (usually measured by total assets or $\log$ of total assets). Size is typically interpreted as reflecting the credit worthiness of the firm. Thus, larger firms are seen to both receive and give more trade credit.

Profitability according to Petersen and Rajan [1] could reflect a number of firm characteristics. Net profit could be taken as a proxy for internal cash generation, and thus one would expect profitable firms to extend more trade credit. Surprisingly, they report a negative relationship between net profits and accounts receivable. Gross profits on the other hand would be an indicator of the incentives to sell. If firms have the ability to discriminate between buyers through the use of trade credit (leading to higher gross margins) then higher the gross profit the 
higher the incentive to sell. They report a positive relationship between gross profits and accounts receivable. Net profits are found to be negatively related to accounts payable. As the firm's ability to generate internal funds increases its tendency to buy on credit decreases. Given that trade credit is extremely expensive this is as expected. Deloof and Jegers [7] also report a negative relationship between net profits and accounts payable. Bougheas et al. [11] find that profitability is positively related to both accounts receivable and accounts payable. This finding is interpreted as extra profit being channeled to accounts receivable and more profitable firms being more credit worthy receive more credit from their suppliers.

Petersen and Rajan [1], report that firms who can secure enough credit from institutional sources have lower accounts payable and point to the possibility that trade credit is a substitute for credit from financial institutions. Other papers like, Kohler, Britton and Yates [5] and Nilsen [24] using different data sets and time periods come to a similar conclusion. Deloof and Jegers [7] using data on Belgian firms provide persuasive evidence that short term bank credit is a substitute for accounts payable. On the other hand, Demirguc-Kunt and Maskimovic [25], in a cross country setting empirically demonstrate that trade credit is a compliment to lending by financial institutions. Cunningham [2] finds that for medium wealth firms (i.e. those firms whose investment is less likely to be constrained by availability of external funs) trade credit and bank credit are substitutes and for low wealth firms (firms whose investments are more likely to be finance constrained) trade credit and bank credit are compliments. This paper provides strong support for the arguments put forward by Burkart and Ellingson [19]. Bougheas et al. [11] find that accounts receivable are compliments to bank loans and accounts payable are substitutes for bank loans. This they argue is clearly indicative of the fact that trade credit is more expensive than bank loans and fits in nicely with the pecking order hypothesis. Thus firms who can borrow from banks are seen to pass on bank credit to their buyers on the one hand and they take less credit on the other.

Inventories have not been used as explanatory variable in empirical studies of trade credit very often. Petersen and Rajan [1] relate the ratio of finished goods inventories to total inventories in the regression analysis with respect to accounts payables and find a strong negative relationship between the two. They argue that the ratio of finished goods inventories to total inventories reflects the "supplier's advantage in liquidating the borrowers assets". If the ratio of finished goods inventories to total inventories is large this reflects a lowering of the supplier's advantage in repossessing and selling supplied goods because the buyer has transformed the raw material supplied into finished goods. Both banks and suppliers may face the same level of difficulty in selling repossessed finished goods. Thus accounts payable of firms with a high ratio of finished goods inventories to total inventories turn out to be lower. Cunat [20] uses inventories as an explanatory variable while explaining accounts payable of firms. He finds a significant and positive relationship. He argues that accounts payable are higher for firms with higher inventories because inventories act as collateral. Bougheas et al. [11] relate finished and semi finished goods inventories to both accounts receivable and accounts payable. They find a strong negative relationship between inventories and accounts receivables. They interpret this as providing strong evidence that firms use trade credit (i.e. allow buyers to delay payment) to increase sales and thus reduce inventories. Inventories turn out to be insignificant when related to accounts payable.

A firms holding of liquid assets (cash and other short term securities) has been used as a determinant of trade credit in a number of papers. Van Horne [26] has argued that firms adopt what is called the matching approach to finance i.e. finance short term needs with short term finance. If such an approach is actually followed by firms then accounts payable should have a positive relationship with holding of liquid assets. Deloof and Jegers [7] find that liquid assets have no influence on accounts payable of Belgian firms. Cunat [20] reports a negative influence of liquid assets on accounts payable. Cunat further shows that when liquid assets fall, this is accompanied by a rise in accounts payable. This finding is interpreted as an adjustment in accounts payable whenever there is an unexpected liquidity shock. Bougheas et al. [11] use liquid assets as an explanatory variable for both accounts payable and accounts receivable. The holding of liquid assets is assumed to have a direct relation to the cost of extending trade credit but theoretically the expected sign for this variable remains indeterminate. They report that liquid assets have a negative and significant influence on accounts receivable and a positive and significant influence on accounts payable.

\section{The Empirical Model and Estimation Results}

\subsection{The Empirical Model}

A model very similar to Bougheas et al. [11] is estimated. They explain trade credit extended (accounts receivable divided by sales) and trade credit received (accounts payable divided by sales) by the same set of explanatory variables. The difference between accounts receivable 
and accounts payable (net trade credit) is considered, in this paper, as an additional dependent variable which shows whether the firm is a net receiver (if this variable has a negative sign) or net giver of trade credit (if this variable has a positive sign). The importance of this variable becomes obvious once it is recognized that firms typically are a part of a credit chain both receiving and offering trade credit. The same set of dependent variables is used to explain this difference as well. The main difference (apart from the fact that an additional variable, net trade credit is considered) in the model estimated in this paper and Bougheas et al. [11] lies in the treatment of inventories. Bougheas et al. [11] define inventories as the level of finished goods and work in progress inventories while our data allows us to segregate inventories into finished goods inventories on the one hand and semi finished goods and raw materials on the other. Finished goods inventories are more likely to influence accounts receivable $\left(\mathrm{AR}^{6}\right)$ while semi finished goods and raw material inventories are more likely to influence accounts payable $\left(\mathrm{AP}^{7}\right)$. By including them separately into the analysis helps in isolating the influence of variable demand (for the firm's product) on accounts receivable and accounts payable. Following Cunat [20] we include the level of collateralizable assets (ratio of fixed assets to total assets) as an explanatory variable. Firms having higher collateralizable assets are expected to have easier access to other sources of credit (including banks) and thus would use less trade credit. Profitability (profits before depreciation interest and taxes) divided by sales, size (log of total assets), liquid assets ${ }^{8}$ and short term bank loans are another standard explanatory variables that we include ${ }^{9}$. The estimated equations take the following form ${ }^{10}$.

$$
\begin{aligned}
& \mathrm{AR}_{\mathrm{i}, \mathrm{t}} / \text { Sales }_{\mathrm{i}, \mathrm{t}}=\alpha_{\mathrm{i}}+\beta_{1} \text { Stocks }_{\mathrm{it}} / \text { Sales }_{\mathrm{it}}+\beta_{2} \text { Size }_{\mathrm{it}} \\
& +\beta_{3} \text { Collateral }_{\text {it }}+\beta_{4} \text { Profits }_{\mathrm{it}} / \text { sales }_{\mathrm{it}} \\
& +\beta_{5} \text { liquid assets }_{\mathrm{it}} / \text { sales }_{\mathrm{it}} \\
& +\beta_{6} \text { short term bank loans }{ }_{\mathrm{it}} / \text { sales }_{\mathrm{it}}+\mathrm{e}_{\mathrm{it}} \\
& \mathrm{AP}_{\mathrm{i}, \mathrm{t}} / \text { Sales }_{\mathrm{i}, \mathrm{t}}=\alpha_{\mathrm{i}}+\gamma_{1} \text { Stocks }_{\mathrm{it}} / \text { Sales }_{\mathrm{it}}+\gamma_{2} \text { Size }_{\mathrm{it}} \\
& +\gamma_{3} \text { Collateral }_{\mathrm{it}}+\gamma_{4} \text { Profits }_{\mathrm{it}} / \text { sales }_{\mathrm{it}} \\
& +\gamma_{5} \text { liquid assets } \mathrm{s}_{\mathrm{it}} / \text { sales }_{\mathrm{it}} \\
& +\gamma_{6} \text { short term bank loans } \mathrm{it}_{\mathrm{it}} / \text { sales }_{\mathrm{it}}+u_{\mathrm{it}} \\
& \left(\mathrm{AR}_{\mathrm{i}, \mathrm{t}}-\mathrm{AP}_{\mathrm{i}, \mathrm{t}}\right) / \text { Sales }_{\mathrm{i}, \mathrm{t}}=\alpha_{\mathrm{i}}+\tau_{1} \text { Stocks }_{\mathrm{it}} / \text { Sales }_{\mathrm{it}}+\tau_{2} \text { Size }_{\mathrm{it}} \\
& +\tau_{3} \text { Collateral }_{\text {it }}+\tau_{4} \text { Profits }_{\mathrm{it}} / \text { sales }_{\mathrm{it}}
\end{aligned}
$$

\footnotetext{
${ }^{6} \mathrm{AR}$ is measured by sundry debtors as reported in the PROWESS database.

${ }^{7} \mathrm{AP}$ is measured by sundry creditors as reported in the PROWESS database.

${ }^{8}$ Liquid assets considered are cash, bank balances and marketable investment.

${ }^{9}$ Except size and collateralizable assets all other variables (both dependent and independent) are normalized by sales.

${ }^{10}$ Bougheas et al. [11] include a variable measuring likelihood of company failure which we do not.
}

$$
\begin{aligned}
& +\tau_{5} \text { liquid assets } \text { sit }_{\mathrm{it}} \text { sales }_{\mathrm{it}} \\
& +\tau_{6} \text { short term bank } \text { loans }_{\mathrm{it}} / \text { sales }_{\mathrm{it}} \\
& +v_{\mathrm{it}}
\end{aligned}
$$

In two other specifications we replace stocks it $_{\text {by }}$ finished goods inventories and semi finished goods inventories plus raw materials inventories.

$\alpha_{\mathrm{i}}$, is a firm specific effect, $\beta_{\mathrm{i}}, \gamma_{\mathrm{i}}$ and $\tau_{\mathrm{i}}$ are the coefficients and $\mathrm{e}_{\mathrm{it}}, u_{\mathrm{it}}$ and $v_{\mathrm{it}}$ are the idiosyncratic error terms. The equations are estimated using a first difference GMM approach which controls for firm specific time invariant effects and for possible endogeniety of regressors $^{11}$. Lags of all the independent variables are used as instruments. Time dummies are included in all the regressions.

We use data from the PROWESS database provided by the Center for Monitoring the Indian Economy (CMIE), Mumbai. This data base contains accounting details of a very large number firms operating in India. The data we use pertains to the 14 year period between 1993 and 2006. From this data base we chose firms which met the following criteria.

(a) Firms with at least five years of continuous data.

(b) Firms whose ratio of manufacturing sales to total sales was in excess of 75 percent for at least half the years for which data were available. This was done to drop firms who had diversified into non manufacturing activities.

(c) Firms with a positive net worth for at least half the number of years for which data were available. This was done to drop firms in financial distress.

(d) Firms with accounts payable and accounts receivable in excess of their total assets were not chosen. This was again done with a view to excluding distressed firms.

(e) Firms needed to be in the private sector. All firms owned by the central and state governments were dropped.

These filters yielded an unbalanced panel of 1522 firms with an average of 10.66 years observations for each firm. The descriptive statistics are provided in Table 1. In general, the mean and medians of accounts receivable are far larger than accounts payable. This is also reflected by the fact that net trade credit has a positive mean and median. The firms in our sample thus, on average, give more trade credit than they receive.

\subsection{Estimation Results}

Tables 2, 3 and 4 report the empirical results with respect to accounts receivable, accounts payable and the difference between accounts receivable and accounts

\footnotetext{
${ }^{11}$ The estimation is performed in stata using the xtabond2 command
} developed by Roodman [27]. 
Table 1. Summary statistics (mean, standard deviation and median).

\begin{tabular}{|c|c|c|c|c|c|}
\hline & & Bottom 25\% & Middle 50\% & Top 25\% & Whole sample \\
\hline \multirow[t]{3}{*}{ Accounts Receivable/sales } & Mean & 0.357 & 0.213 & 0.175 & 0.240 \\
\hline & Std. Dev & 3.620 & 1.496 & 0.172 & 2.101 \\
\hline & Median & 0.184 & 0.165 & 0.144 & 0.162 \\
\hline \multirow[t]{3}{*}{ Accounts Payable/sales } & Mean & 0.210 & 0.157 & 0.157 & 0.170 \\
\hline & Std. Dev & 0.496 & 0.299 & 0.306 & 0.361 \\
\hline & Median & 0.120 & 0.116 & 0.125 & 0.120 \\
\hline \multirow[t]{3}{*}{ (Accounts Receivable-Accounts payable)/sales } & Mean & 0.147 & 0.057 & 0.018 & 0.070 \\
\hline & Std. Dev & 3.496 & 1.456 & 0.302 & 2.036 \\
\hline & Median & 0.050 & 0.042 & 0.018 & 0.038 \\
\hline \multirow[t]{3}{*}{ Inventories/sales } & Mean & 0.193 & 0.127 & 0.113 & 0.140 \\
\hline & Std. Dev & 0.846 & 0.262 & 0.218 & 0.476 \\
\hline & Median & 0.079 & 0.079 & 0.079 & 0.079 \\
\hline \multirow[t]{3}{*}{ Finished good inventories/sales } & Mean & 0.119 & 0.086 & 0.081 & 0.093 \\
\hline & Std. Dev & 0.438 & 0.230 & 0.195 & 0.290 \\
\hline & Median & 0.041 & 0.045 & 0.052 & 0.046 \\
\hline \multirow[t]{3}{*}{ Raw material inventories/sales } & Mean & 0.245 & 0.127 & 0.107 & 0.152 \\
\hline & Std. Dev & 2.614 & 0.317 & 0.176 & 1.331 \\
\hline & Median & 0.086 & 0.090 & 0.079 & 0.086 \\
\hline \multirow[t]{3}{*}{ Fixed assets/Total assets } & Mean & 0.637 & 0.636 & 0.670 & 0.645 \\
\hline & Std. Dev & 0.348 & 0.279 & 0.264 & 0.295 \\
\hline & Median & 0.601 & 0.631 & 0.670 & 0.634 \\
\hline \multirow[t]{3}{*}{ Profit/sales } & Mean & 0.035 & 0.101 & 0.159 & 0.099 \\
\hline & Std. Dev & 4.508 & 1.544 & 0.158 & 2.508 \\
\hline & Median & 0.087 & 0.120 & 0.149 & 0.121 \\
\hline \multirow[t]{3}{*}{ Liquid Assets/sales } & Mean & 0.363 & 0.088 & 0.100 & 0.160 \\
\hline & Std. Dev & 6.708 & 0.697 & 0.342 & 3.399 \\
\hline & Median & 0.028 & 0.027 & 0.043 & 0.031 \\
\hline \multirow[t]{3}{*}{ Bank loans/sales } & Mean & 0.351 & 0.205 & 0.154 & 0.229 \\
\hline & Std. Dev & 3.722 & 2.335 & 0.319 & 2.495 \\
\hline & Median & 0.105 & 0.120 & 0.105 & 0.113 \\
\hline \multirow[t]{3}{*}{ Size } & Mean & 2.023 & 3.822 & 5.916 & 3.894 \\
\hline & Std. Dev & 0.662 & 0.670 & 0.931 & 1.566 \\
\hline & Median & 2.111 & 3.805 & 5.716 & 3.803 \\
\hline
\end{tabular}

Note: Firms are separated into size categories by using a dummy variable which takes the value of 1 in a given year if the firms total assets are in the top 25, middle 50 and bottom 25 percentile of the distribution of total assets of all the firms in that year.

payable (net trade credit) respectively. Column 1 refers to the specification where total inventories are used as an independent variable and column 2 refers to the specification where inventories are bifurcated into finished goods and raw material inventories ${ }^{12}$.

The inventory to sales ratio is negatively (the coeffi- cient is significant at $5 \%$ ) related to accounts receivable. When inventories are split into finished goods inventories and raw material and semi finished inventories the coefficient on finished goods inventories has a negative sign and is significant at $1 \%$. The coefficient of raw material inventories turns out to be positive but insignificant. 
Table 2. Accounts receivable.

\begin{tabular}{ccc}
\hline & 1 & 2 \\
\hline Inventories/sales & $-0.715^{* * *}$ & \\
& $(0.312)$ & \\
Finished good inventories/sales & & $-0.915^{* * *}$ \\
Raw material inventories/sales & & $(0.306)$ \\
& & 0.032 \\
Fixed assets/total assets & $0.622^{*}$ & $0.2091)$ \\
Profit/sales & $(0.376)$ & $(0.481)$ \\
& $-0.455^{* *}$ & $-0.557^{* * *}$ \\
Liquid assets/sales & $(0.195)$ & $(0.202)$ \\
& $0.833^{* * *}$ & $0.823^{* * *}$ \\
Bank loans/sales & $(0.013)$ & $(0.016)$ \\
& -0.034 & $-0.049^{* * *}$ \\
Size & $(0.022)$ & $(0.023)$ \\
& $1.427^{* * *}$ & 1.013 \\
No. of observations & $(0.530)$ & $(0.663)$ \\
m1(p) & & \\
m2 (p) & 11609 & 11609 \\
Hansen/Sargan & 0.00 & 0.00 \\
& 0.281 & 0.231 \\
& 0.958 & 0.988 \\
\hline
\end{tabular}

Test statistics and standard errors (in parentheses) are asymptotically robust to heteroscedasticity. (m2) is a test for first order serial correlation in levels, asymptotically distributed as $\mathrm{N}(0,1)$ under the null of no serial correlation. The Hansen/Sargan test is a test of over identifying restrictions distributed as chi-square under the null of instrument validity. Both equations are estimated using a GMM first difference specification. The instruments include first and second lags of Inventory/sales, Finished good inventories/sales, Raw material inventories/sales, Fixed assets/total assets, Profit/sales, Liquid assets/sales, Bank loans/sales and Size. Time dummies were always included as regressors and instruments. ${ }^{*},{ }^{* * *}$, and ${ }^{* * *}$ indicate significance at $10 \%, 5 \%$ and $1 \%$ respectively.

This indicates that firms with lower finished goods inventories have higher accounts receivable and thus firms offer more trade credit to boost sales and lower finished goods inventories. Inventory management is thus an important motive for firms to offer trade credit to other firms.

Profits have a negative coefficient which is significant in both specifications. Profitable firms thus do not offer higher trade credit. This finding is contrary to what is found in the literature where generally speaking a posi-

\footnotetext{
${ }^{12}$ Following Bougheas et al. [11] an interaction term between size and inventories was tried to reflect the influence of size on costs of holding inventories. The coefficient for this interaction variable turned out to be insignificant in all specifications and was dropped. A dummy variable representing membership of industrial group was introduced and this turned out to be insignificant in all specifications. In the initial phases of the empirical investigation industry dummies of 32 NIC 2 digit level industries were created. Very few of these dummies turned out to be significant in any of the specifications. These were subsequently dropped in later specifications.

${ }^{13}$ See Athey and Lumas [28], Ganesk-Kumar, Sen and Vaidya [29], Lensink, Remco and Gangopadhay [30] amoung others.
}

Table 3. Accounts payable.

\begin{tabular}{ccc}
\hline & 1 & 2 \\
\hline Inventory/sales & $0.103^{* * *}$ & \\
Finished good inventories/sales & $(0.061)$ & \\
& & $0.256^{* * *}$ \\
Raw material inventories/sales & & $(0.049)$ \\
& & $0.104^{* * *}$ \\
Fixed assets/total assets & -0.171 & -0.073 \\
& $(0.131)$ & $(0.118)$ \\
Profit/sales & $-0.079^{* * *}$ & -0.025 \\
& $(0.034)$ & $(0.027)$ \\
Liquid assets/sales & $0.033^{* * *}$ & $0.034^{* * *}$ \\
& $(0.002)$ & $(0.001)$ \\
Bank loans/sales & $0.024^{* * *}$ & $0.027^{* *}$ \\
& $(0.011)$ & $(0.011)$ \\
Size & -0.070 & -0.218 \\
& $(0.172)$ & $(0.158)$ \\
No. of observations & & \\
m1(p) & 11609 & 11609 \\
m2 (p) & 0.084 & 0.269 \\
Hansen/Sargan & 0.333 & 0.374 \\
& 0.410 & 0.870 \\
\hline
\end{tabular}

Test statistics and standard errors (in parentheses) are asymptotically robust to heteroscedasticity. (m2) is a test for first order serial correlation in levels, asymptotically distributed as $\mathrm{N}(0,1)$ under the null of no serial correlation. The Hansen/Sargan test is a test of over identifying restrictions distributed as chi-square under the null of instrument validity. Both equations are estimated using a GMM first difference specification. The instruments include first and second lags of Inventory/sales, Finished good inventories/sales, Raw material inventories/sales, Fixed assets/total assets, Profit/sales, Liquid assets/sales, Bank loans/sales and Size. Time dummies were always included as regressors and instruments. ${ }^{* * * *}$, and ${ }^{* * * *}$ indicate significance at $10 \%, 5 \%$ and $1 \%$ respectively.

tive and significant coefficient is common [Petersen and Rajan [1] and Bougheas et al. [11]. The result is consistent with the Burkart and Ellingsen [19] argument that profitable but finance constrained firms would prefer not to offer trade credit. The relevance of this argument is strengthened by the finding of a number of papers that investment by firms in India is finance constrained ${ }^{13}$. The negative coefficient also calls in question the relevance of the price discrimination motive for offering trade credit.

The coefficient of bank loans is negative and significant in specification 2. Bougheas et al. [11] report a positive and significant coefficient for bank loans. Bank loans and accounts receivable turn out to be substitutes. The fact that banks do not accept account receivables as collateral could be driving this result. Clearly those firms having access to bank finance do not pass this on as accounts receivable to their customers.

Liquid assets have a positive and significant coefficient in both the specifications. This again is contrary to 
Table 4. Accounts receivable-accounts payable.

\begin{tabular}{ccc}
\hline & 1 & 2 \\
\hline Inventory/sales & $-0.354^{* * *}$ & \\
& $(0.172)$ & $-1.185^{* * *}$ \\
Finished good inventories/sales & & $(0.287)$ \\
Raw material inventories/sales & & $-0.065^{* *}$ \\
& & $(0.038)$ \\
Fixed assets/total assets & 0.713 & 0.249 \\
Profit/sales & $(0.448)$ & $(0.548)$ \\
& $-0.0 .401^{* *}$ & $-0.558^{* * *}$ \\
Liquid assets/sales & $(0.223)$ & $(0.202)$ \\
& $0.795^{* * *}$ & $0.790^{* * *}$ \\
Bank loans/sales & $(0.015)$ & $(0.015)$ \\
& $-0.056^{* *}$ & $-0.074^{* * *}$ \\
Size & $(0.023)$ & $(0.021)$ \\
& $1.375^{* *}$ & 1.039 \\
& $(0.664)$ & $(0.782)$ \\
Honsen/Sargan & & \\
m2 (p) & 11609 & 11609 \\
Hobservations & 0.377 & 0.352 \\
& 0.661 & 0.128 \\
& 0.997 & 0.998 \\
\hline
\end{tabular}

Test statistics and standard errors (in parentheses) are asymptotically robust to heteroscedasticity. (m2) is a test for first order serial correlation in levels, asymptotically distributed as $\mathrm{N}(0,1)$ under the null of no serial correlation. The Hansen/Sargan test is a test of over identifying restrictions distributed as chi-square under the null of instrument validity. Both equations are estimated using a GMM first difference specification. The instruments include first and second lags of Inventory/sales, Finished good inventories/sales, Raw material inventories/sales, Fixed assets/total assets, Profit/sales, Liquid assets/sales, Bank loans/sales and Size. Time dummies were always included as regressors and instruments. ${ }^{*},{ }^{* *}$, and ${ }^{* * *}$ indicate significance at $10 \%, 5 \%$ and $1 \%$ respectively.

what Petersen and Rajan [1] and Bougheas et al. [11] report. The coefficient of collateralizable assets turns out to be positive and significant at the 10 percent level in specification 1 and insignificant in specification 2. Size turns out to be positive and significant at 10 percent in specification 1 and insignificant in specification 2. This again is contrary to the general finding that large firms offer more trade credit.

As regards accounts payable the coefficient of inventories has a positive sign but is significant only at the 10 percent level in specification 1. When we bifurcate inventories both finished goods and raw material inventories have a positive and significant sign with the coefficient of finished goods inventories being much larger. When firms pile up both types of inventories they take more trade credit. Trade credit is thus offered to firms who encounter a negative shock to sales. In this case too profits turn out to be negative and significant. This is contrary to what Bougheas et al. [11] find. More profit- able firms thus neither offer nor take more trade credit. Liquid assets have a positive and significant sign and this time this result in line with Bougheas et al. [11]. This turns out to be consistent with the Van Horne [26] view of a matching approach to finance. Moreover possession of liquid assets could signal an ability to pay back on time.

The coefficient of bank loans has a positive and significant sign. This is consistent with the Burkart and Ellingsen [19] view that bank credit and trade credit would be compliments for firms who are likely to face binding finance constraints. This again is contrary to Bougheas $e t$ al. [11] findings. Size does not turn out to be significant in any of the specifications.

Turning to results for net trade credit (accounts receivable-accounts payable) the coefficient of total inventories is negative and significant at 5 percent. Once the inventories are bifurcated both finished goods and raw material inventories have a negative and significant coefficient. What is important is that the finished goods inventories have a much larger coefficient. Thus it is finished good inventories that are more influential in determining net trade credit given. The coefficients of profits and bank loans have a negative and significant sign while liquid assets have a positive and significant sign. Size turns out to be insignificant in both specifications.

\section{Conclusions}

The empirical evidence presented suggests that in the Indian context strong evidence exists in support of an inventory management motive for offering trade credit. Firms attempt to increase sales and lower finished goods inventories by offering trade credit both on a gross and net basis. When inventories of finished goods and semi finished goods and raw materials rise firms tend to postpone payments to their supplier and this shows up on their books of accounts as higher accounts payable. This is likely to help firms tide over negative shocks to sales. Thus trade credit in general can be seen to arise as a financial response to variable demand for their finished goods. Highly profitable firms are found to both give (on both net and gross basis) and receive less trade credit. There could be many underlying results for this finding. Firstly more profitable firms may not face a major problem with respect to variability of demand for their product. The need to offer trade credit for inventory management is thus smaller. Moreover the need to accept trade credit for such firms would also be lower, as inventories would rarely he high. Secondly, as argued by Burkart and Ellingsen [19], profitable but finance constrained firms would prefer not to offer trade credit. The 
fact that the coefficients of profitability are negative, price discrimination does not seem to be a motive for the existence of trade credit in India.

Firm's holdings of liquid assets have a positive influence on accounts receivable and accounts payable and net trade credit. Firms with greater access to bank credit offer less trade credit to their customers. Firms with more access to bank funds do not pass them on to their buyers as accounts receivable. On the other hand, firms with higher bank loans receive more trade credit. The empirical results on the determinants of trade credit in India are very different from those for advanced countries.

\section{Acknowledgements}

I would like to thank Dr. S. Chandrashekhar and Dr. Naveen Srinivasan for helpful discussions and Mr. Ankush Agarwal for help with the GMM estimation. Mr. Ashish Singh provided efficient research assistance.

\section{References}

[1] M. A. Petersen and R. G. Rajan, "Trade Credit: Theories and Evidence,” The Review of Financial Studies, Vol. 10, No. 3, 1997, pp. 661-691. doi:10.1093/rfs/10.3.661

[2] R. Cunningham, "Trade Credit and Credit Rationing in Canadian Firms,” Bank of Canada Working Paper 49, 2004.

[3] C. Ng, J. Smith and R. Smith, "Evidence on the Determinants of Credit Terms in Inter firm Trade," Journal of Finance, Vol. 54, No. 6, 1999, pp. 1109-1129. doi:10.1111/0022-1082.00138

[4] R. G. Rajan and L. Zingales, "What Do We Know About Capital Structure? Some Evidence from International Data,” Journal of Finance, Vol. 50, No.5, 1995, pp. 1421-1460. doi: $10.2307 / 2329322$

[5] M. Kohler, E. Britton and T. Yates, "Trade Credit and the Monetary Transmission Mechanism,” Bank of England Working Paper ISSN 1368-5562, 2000.

[6] I. Uesugi and G. M. Yamashiro, "How Trade Credit Differs from Loans: Evidence from Japanese Trading Companies,” RIETI Discussion Paper Series 04-E-028, 2004.

[7] M. Deloof and M. Jegers, "Trade Credit, Corporate Groups and the Financing of Belgian Firms," Journal of Business Finance and Accounting, Vol. 26, No.7, 1999, pp. 945-966. doi:10.1111/1468-5957.00281

[8] Reserve Bank of India, "Reserve Bank of India Bulletin,” Mumbai, March 2010.

[9] Reserve Bank of India, "Report of the Working Group on Discounting of Bills by Banks,” Mumbai, 2000.

[10] Reserve Bank of India, "Basic Statistical Returns of Scheduled Commercial Banks in India,” Mumbai, 2010.

[11] S. Bougheas, S. Mateut and P. Mizen, “Corporate Trade
Credit and Inventories: New Evidence of a Trade-Off from Accounts Payable and Receivable," Journal of Banking and Finance, Vol. 33, No. 2, 2009, pp. 300-307. doi:10.1016/j.jbankfin.2008.07.019

[12] A. H. Metzler, "Mercantile Credit, Monetary Policy and Size of Firms," The Review of Economics and Statistics, Vol. 42, No.4, 1960, pp. 429-437. doi:10.2307/1925692

[13] A. Guariglia and S. Mateut, "Credit Channel, Trade Credit Channel and Inventory Investment: Evidence from a Panel of U.K. Firms,” Journal of Banking and Finance, Vol. 30, No. 10, 2006, pp. 2835-2856. doi:10.1016/j.jbankfin.2005.11.002

[14] S. Mateut, S. Bougheas and P. Mizen, "Trade Credit, Bank Lending and Monetary Policy Transmission,” European Economic Review, Vol. 50, No. 3, 2006, pp. 603629. doi:10.1016/j.euroecorev.2005.01.002

[15] M. J. Brennan, V. Maksimovic and J. Zechner, "Vendor Financing," Journal of Finance, Vol. 43, No. 5, 1988, pp. 1127-1141.

[16] R. Schwartz, “An Economic Model of Trade Credit,” Journal of Financial and Quantitative Analysis, Vol. 9, No. 4, 1974, pp. 643-657. doi:10.2307/2329765

[17] B. Biais and C. Gollier, "Trade Credit and Credit Rationing,” Review of Financial Studies, Vol. 10, No. 4, 1997, pp. 903-937. doi:10.1093/rfs/10.4.903

[18] N. Jain, “Monitoring Costs and Trade Credit," Quarterly Review of Economics and Finance, Vol. 41, No. 1, 2001, pp. 89-110. doi:10.1016/S1062-9769(00)00063-6

[19] M. Burkart and T. Ellingson, "In-Kind Finance: A Theory of Trade Credit," American Economic Review, Vol. 94, No. 3, 2004, pp. 569-590. doi:10.1257/0002828041464579

[20] V. Cunat, "Trade Credit: Suppliers as Debt Collectors and Insurance Providers," The Review of Financial Studies, Vol. 20, No. 2, 2007, pp. 491-527. doi:10.1093/rfs/hhl015

[21] Y. W. Lee and J. D. Stowe, "Product Risk, Asymmetric Information and Trade Credit," The Journal of Financial and Quantitative Analysis, Vol. 28, No. 2, 1993, pp. 285300. doi:10.2307/2331291

[22] G. Emery, “An Optimal Financial Response to Variable Demand," Journal of Finance and Quantitative Analysis, Vol. 22, No. 2, 1987, pp. 209-225. doi:10.2307/2330713

[23] Y. Miwa and J. M. Ramseyer, "Trade Credit, Bank Loans and Monitoring: Evidence from Japan,” CARF Working Paper F-054, 2005.

[24] J. Nilsen, "Trade Credit and the Bank Lending Channel," Journal of Money Credit and Banking, Vol. 34, No. 1, 2002, pp. 226-253. doi:10.1353/mcb.2002.0032

[25] A. Demirguc-Kunt and V. Maksimovic, "Firms as Financial Intermediaries: Evidence from Trade Credit Data," World Bank Research Working Paper No. 2696, 2001.

[26] J. Van Horne, "Financial Management and Policy,” Prentice Hall, UK, 1995.

[27] D. Roodman, "Xtabond2:Stat Module to Extend Xtabond Dynamic Panel Data Estimator,” Center for Global De- 
velopment, Washington, 2005.

[28] M. J. Athey and P. S. Laumas, "Internal Funds and Corporate Investments in India," Journal of Development Economics, Vol. 45, No. 2, 1994, pp. 287-303. doi:10.1016/0304-3878(94)90034-5

[29] A. Ganesh_Kumar, K. Sen and R. R. Vaidya, "Outward Orientation, Investment and Finance Constraints: A Study of Indian Firms,” Journal of Development Studies, Vol.
37, No. 4, 2001, pp. 133-149. doi:10.1080/00220380412331322071

[30] R. Lensink, R. van der Molen and S. Gangopadhay, "Business Groups, Financing Constraints and Investment: The Case of India,” Journal of Development Studies, Vol. 40, No. 2, 2003, pp. 93-119. doi:10.1080/00220380412331293787 